\title{
Measurement of Total Lung Capacity: A Comparison of Spiral CT and Spirometry ${ }^{1}$
}

\author{
Kyung II Chung, M.D., Kyung Ju Park, M.D., Eh Hyung Lee, M.D. ${ }^{2}$, Kyu Ok Choe, M.D ${ }^{3}$., \\ Tae-Hwan Lim, M.D ${ }^{4}$, In Hyuk Chung, M.D. ${ }^{5}$, Heun Young Yune, M.D., Jung Ho Suh, M.D.
}

Purpose: To determine the potential of spiral CT as a functional imaging modality of the lung aside from its proven value in morphological depiction.

Materials and Methods: Spiral CT scan was performed in ten normal female and nine normal male adults (mean age : 39 , height : $163 \mathrm{~cm}$, weight : $62 \mathrm{~kg}$ ) after single full breath-holding. Three dimensional lung images were reconstructed(minimal threshold value: $-1,000 \mathrm{HU}$, maximal threshold values: $-150,-250,-350,-450$ $\mathrm{HU})$ to obtain total lung volume(TLV) on a histogram. Total lung volume measured by spiral CT was compared with TLV obtained by spirometry.

Results : Mean TLV measured by spirometry was $5.62 \mathrm{~L}$ and TLV measured by CT at maximal threshold values of $-150,-250,-350$, and $-450 \mathrm{HU}$ was $5.53,5.33,5$. 15 , and $4.98 \mathrm{~L}$, respectively. Mean absolute differences between the modalities of $0.17 \mathrm{~L}(3 \%), 0.32 \mathrm{~L}(5.6 \%), 0.48 \mathrm{~L}(8.5 \%), 0.65 \mathrm{~L}(11.5 \%)$ were statistically significant $(p<0.001)$. Linear regression coefficients between the modalities were 0.99 , $0.97,0.95$, and 0.94 and no statistically significant differences in accuracy of threshold levels in the estimation of lung volume $(r=0.99$, standard error $=0.034 \mathrm{~L}$ in all) were seen.

Conclusion : TLV measured by spiral CT closely approximated that measured by spirometry. Spiral CT may be useful as a means of evaluating lung function.

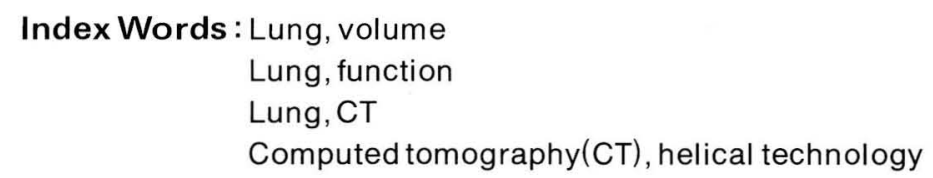

\section{INTRODUCTION}

In addition to its ability to depict the morphologic characteristics of the lung in great detail, computed tomography $(\mathrm{CT})$ can be helpful in the evaluation of physiologic and pathologic changes of the lung. In addition to the direct visual scoring method, computer analysis of attenuation maps of lung parenchyma has been used to study diffuse lung diseases and to correlate it with pulmonary function $(1-5)$. Few attempts to

\footnotetext{
Department of Diagnostic Radiology, Ajou University School of Medicine ${ }^{2}$ Department of Pulmonology, Ajou University School of Medicine ${ }^{3}$ Department of Diagnostic Radiology, College of Medicine, Yonsei University ${ }^{4}$ Departement of Anatomy, College of Medicine, Yonsei University

${ }^{5}$ Department of Diagnostic Radiology, University of Ulsan College of Medicine Received October 23, 1995 ; Accepted May 31, 1996

Address reprint requests to: Kyung II Chung, M.D., Department of Diagnostic

Radiology, College of Medicine, Ajou University

\# 5, Won Chun Dong, Pal Dal Gu, Su Won, Kyung Gi Do 442-749 Korea.

Tel. 82-331-219-5857 Fax. 82-331-219-5862
}

utilize CT as a functional test of the lung have been made. Wandtke et al(6). found that measurement of lung volume by CT underestimated by $34 \%$ that measured by the helium inhalation technique. Wu et al.(1) found, however, that CT was effective in predicting forced expiratory volume in 1 second and forced vital capacity using TLV measured by CT. These studies used conventional CT with multiple breath-holdings, which might have resulted in inaccurate scan location at each breath-holding state, and manually manipulated ROls. Contrary to the scope of window width in CT volume measurement, no attempt to determine the optimal upper limit of lung attenuation has been made(1). The authors performed this study to determine whether or not the single breath-hold technique using spiral CT with fully automated $\mathrm{ROI}$ manipulation can narrow the difference between TLV measured by CT and spirometry and to determine the optimal upper limit of lung attenuation in measuring total lung volume. 


\section{MATERIALS and METHODS}

Eleven normal female(mean age : 41 , height : $155 \mathrm{~cm}$, weight : $55 \mathrm{~kg}$ ) and nine normal male adults (mean age : 36 , height: $171 \mathrm{~cm}$, weight: $70 \mathrm{~kg}$ ) practiced the technique of full breath-holding before a CT scan. Spiral CT scan was performed with GE HighSpeed Advantage (GE Medical Systems, Milwaukee, WI) with the subject in supine position and single full breath-holding state. Scan parameters used were collimation of $10 \mathrm{~mm}$, pitch factor of 1, $120 \mathrm{kVp}$ and $200 \mathrm{mAs}$. Images were reconstructed using a standard reconstruction algorithm with a matrix size of $512 \times 512$, reconstruction interval of $10 \mathrm{~mm}$, and display FOV of $32 \mathrm{~cm}$. The im-ages of the lung were reconstructed three dimens- ionally using a software(GE Advantage Window, Mil- waukee, WI) in volume mode with threshold range of -150 to $-1,000$ $\mathrm{HU}$ for the automatic removal of stru- ctures surrounding the lung. In the cases of incomplete removal, scalpeling of the unwanted structures was carried out in shaded surface display mode with the aid of multiplanar reformation. Lung volume on histogram was evaluated at maximal threshold values of -150 , $-250,-350$, and $-450 \mathrm{HU}$ so that the results could be compared with those obtained by spirometry to determine the optimal threshold range. Spirometry(PF/Dx 1085D Breeze; Medgraphics, St Paul, MN) was performed within one week of CT studies. Lung volume measured by CT with various threshold ranges was compared with that measured by spirometry using linear regression analysis.

\section{RESULTS}

Mean TLV measured by spirometry and CT at maximal threshold value of $-150 \mathrm{HU}$ was 5.62 and $5.53 \mathrm{~L}$, respectively(Table 1). The mean of absolute difference between TLV obtained by spirometry and CT at maximum threshold value of $-150 \mathrm{HU}$ was $0.17 \mathrm{~L}(3 \%)$ which was the least mean absolute difference obtainable by the variable threshold ranges(Table 2). A progressive significant increase in mean absolute difference was noted according to the decrease in maximal threshold values(Bartletts'test, $\mathrm{p}<0.001$ ) with a maximal mean absolute difference of $0.65 \mathrm{~L}(11.5 \%)$ at $-450 \mathrm{HU}$. At maximal threshold of $-150 \mathrm{HU}$, the mean absolute difference of $0.14 \mathrm{~L}$ in males was smaller than the difference of $0.20 \mathrm{~L}$ in females, but with a decrease in maximal threshold the values were progressively reversed so that at $-450 \mathrm{HU}$, the mean absolute difference of 0 . $68 \mathrm{~L}$ in males was larger than the $0.62 \mathrm{~L}$ found in females.

Minute but progressive decrease in standard deviation and standard error of difference between TLV measured by spirometry and by CT were noted as the threshold increased, with respective minimal values of 0.11 and 0.01 at $-150 \mathrm{HU}($ Table 3 ).

TLV in three cases measured by CT at a maximum threshold of $-150 \mathrm{HU}$ and in two of the three cases at $-250 \mathrm{HU}$, was larger than that by spirometry, suggesting inappropriately high threshold values for optimal depiction of only the lung tissues at these ranges. However, linear regression analysis showed the highest regression coefficient(b), 0.99, and the highest coefficient of determination $\left(r^{2}\right), 0.981$, between TLV measured by spirometry(y) and by $\mathrm{CT}(\mathrm{x})$ at $-150 \mathrm{HU}$ (Table 4)(Fig. 1.). Subsequently decreasing coefficient values were noted with a decrease in maximal threshold values ; this suggested the more predominant exclusion of borderline pixel values of lung parenchyma relative to the inclusion of borderline extraparenchymal pixel values as the maximal threshold decreased. The highest coefficent values at $-150 \mathrm{HU}$, pointed to an optimal balance between discriminatory exclusion and inclusion of the pixel values. In spite of the minute difference in coefficients, there was no statistically signifi-

Table 2. Mean Absolute TLV Difference between Spirometry and Spiral CT

\begin{tabular}{lcccc}
\hline \hline & \multicolumn{3}{c}{ Spiral CT(Max. Threshold; HU) } \\
\cline { 2 - 5 } & -150 & -250 & -350 & -450 \\
\hline Female & 0.20 & 0.32 & 0.46 & 0.62 \\
Male & 0.14 & 0.32 & 0.49 & 0.68 \\
\hline Average & 0.17 & 0.32 & 0.48 & 0.65 \\
& $(3 \%)$ & $(5.6 \%)$ & $(8.5 \%)$ & $(11.5 \%)$ \\
\hline
\end{tabular}

Note. -Data indicate liter $T L V=$ total lung volume

Table 1. Mean Total Lung Volume(TLV) measured by Spirometry and Spiral CT

\begin{tabular}{|c|c|c|c|c|c|c|c|c|c|}
\hline & Age & Height(cm) & Weight(kg) & \multicolumn{2}{|c|}{ Spirometry } & \multicolumn{4}{|c|}{ Spiral CT(Max. Threshold; HU) } \\
\hline Female $(n=10)$ & 41 & 155 & 55 & 115 & $4.59 L$ & $4.47 \mathrm{~L}$ & $4.28 \mathrm{~L}$ & $4.13 \mathrm{~L}$ & $3.97 \mathrm{~L}$ \\
\hline Average & 39 & 163 & 62 & 119 & $5.62 \mathrm{~L}$ & $5.53 \mathrm{~L}$ & $5.33 \mathrm{~L}$ & $5.15 \mathrm{~L}$ & $4.98 \mathrm{~L}$ \\
\hline
\end{tabular}

Note. - * Percentile relative to standard according to sex, age, height, weight, and race $\mathrm{TLV}=$ total lung volume 
cant difference between the accuracy of the threshold levels in estimation of lung volume, as the standard error of estimate, $0.034 \mathrm{~L}$, was the common value in all (Table 4).

\section{DISCUSSION}

TLV measured by CT in three patients at a maximal threshold of $-150 \mathrm{HU}$, and in two of the three patients at $-250 \mathrm{HU}$, was larger than that by spirometry. These readings included two females with TLV\% in spirometry(percentile relative to standard, according to sex, age, height, weight, and race) of $108 \%$ and $118 \%$ (mean $115 \%$ ) and one male with that of $114 \%$ (mean $124 \%$ ).
The standard TLV data provided by the spirometry equipment might not be the most up-to-date nor representative of the most accurate, as evidenced by the high mean TLV\% of the normal subjects in this study. The relatively lower TLV\% in two of the three cases with TLV higher as measured by CT than by spirometry might suggest, then, the possible limitation of spirometry in those with poor compliance for spirometry(7). Other possible explanations may include individually variable extra- and intra-parenchymal tissue densities which may have lead to selective inclusion of extraparenchymal tissue in the three cases, perhaps pointing to the advantage of application of variable threshold ranges upon individual bases(8). Rather than

Table 3. Standard Deviation/Error of TLV Difference

\begin{tabular}{lcccc}
\hline \hline & \multicolumn{4}{c}{ Spiral CT(Max. Threshold; HU) } \\
\cline { 2 - 4 } & -150 & -250 & -350 & -450 \\
\hline Female & ${ }^{*} 0.11(0.01)$ & $0.18(0.03)$ & $0.20(0.04)$ & $0.20(0.04)$ \\
Male & $0.11(0.01)$ & $0.12(0.01)$ & $0.19(0.04)$ & $0.20(0.04)$ \\
\hline Average & $0.11(0.01)$ & $0.15(0.02)$ & $0.19(0.04)$ & $0.20(0.04)$ \\
\hline
\end{tabular}

Note. $-{ }^{*}$ Standard deviation(standard error)

Data indicate liter

$\mathrm{TLV}=$ total lung volume

Table 4. Linear Regression Analysis of TLV : Spirometry(x), Spiral CT(y)

\begin{tabular}{lcccc}
\hline \hline \multirow{2}{*}{ Coefficient } & \multicolumn{4}{c}{ Spiral CT(Max. Threshold; HU) } \\
\cline { 2 - 4 } & -150 & -250 & -350 & -450 \\
\hline Regression(b) & 0.99 & 0.97 & 0.95 & 0.94 \\
Intercept(a) & -0.048 & -0.148 & -0.203 & -0.305 \\
Determination( $\left.r^{2}\right)$ & 0.981 & 0.980 & 0.979 & 0.978 \\
Correlation(r) & 0.99 & 0.99 & 0.99 & 0.99 \\
StandardError & 0.034 & 0.034 & 0.034 & 0.034 \\
\hline
\end{tabular}

Note. $-T L V=$ total lung volume
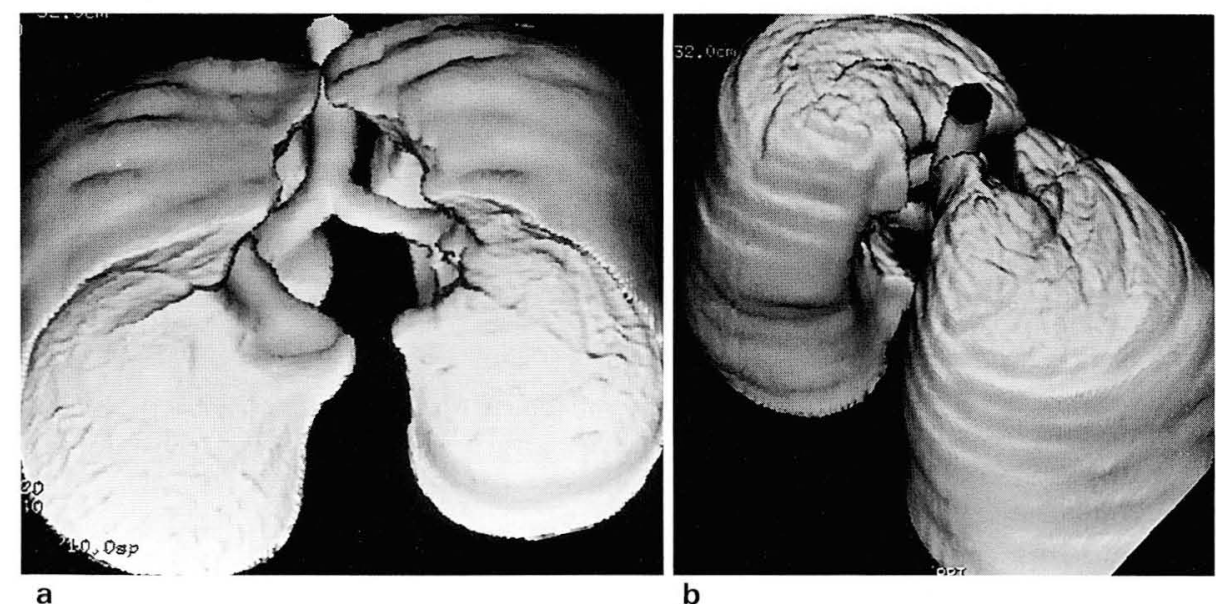

b
Fig. 1. Shaded surface display of a lung reconstructed three dimensionally using threshold range of -150 to $-1000 \mathrm{HU}$. Anterior oblique(a) and posterior oblique(b) views show the lung free of surrounding structures. 


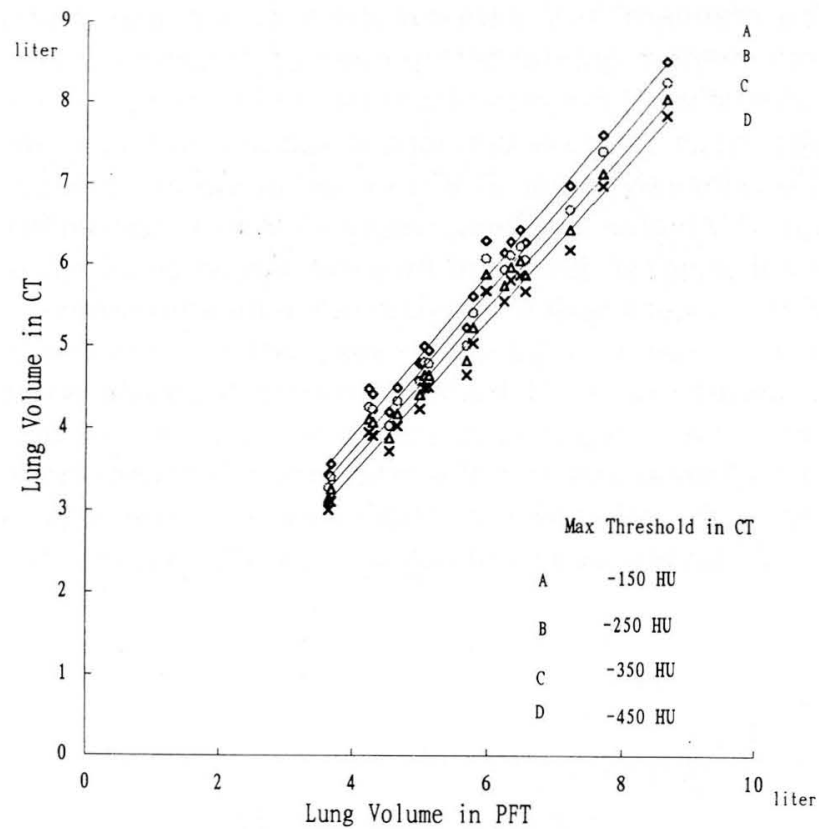

Fig. 2. Linear regression between lung volume measured by spiral CT(abscissa) at maximal threshold values of $-150,-250$, $-350,-450 \mathrm{HU}$ and by spirometry(ordinate). Correlation coefficients are displayed in Table 4.

selective inclusion in the three cases, the inclusion of extraparenchymal tissue in all cases should also be considered, as the mean difference between TLV measured by spirometry and by CT was smaller at these higher maximal thresholds. The fact that the interphase area between extra- and intra-parenchymal tissue increases with larger lung volume partly explains the larger mean TLV difference, of below $-250 \mathrm{HU}$, in males than in females. The progressively increasing discrepancy between the values in male and female at a lower maximal threshold occurred due to more extraction of intraparenchymal tissue in male with larger interphase area. Conversely, the discrepancy between the mean TLV differences in male and females became reversed above $-250 \mathrm{HU}$, with the smaller TLV difference in males than in females caused by the addition of more extraparenchymal tissue in males with larger interphase area. This may also explain the highest regression coefficient between TLV measured by PFT and by CT, and the smallest standard deviation of TLV differences at $-150 \mathrm{HU}$. The optimal maximal threshold level may be $-250 \mathrm{HU}$, since at this level there was no discrepancy between mean TLV difference in femalesad in males. However, further study, using improved scanning techniques, is needed for more definitive results.

There have been very few reports on lung volume measurements using CT. A previous study(9) on CT estimation of lung volume in children described a correlation coefficient of 0.92 between the value as determined by $\mathrm{CT}$ and by spirometry. One other previous study $(10)$ in adults reported a coefficient of 0.81 . These are lower values than the result of this study $(r=0.99)$. Apart from CT technical factors, strict adherance to patient cooperation in breath-holding practices before CT scanning and repetition of studies in some may have contributed to the result.

Spiral CT with its fast scanning ability, makes possible lung volume measurement during a single full breath-holding, thereby minimizing error caused by changes in scan location due to multiple breath-holding. However, the speed of scanning in spiral CT is still not the most desirable for optimal depiction of lung volume, as the minimum scan duration of 1 second limits the maximum number of scans during a single breathholding to 30 . (It was the authors experience that 30 seconds was more or less the safest duration of a full breath-holding for all patients positioned with in the CT gantry.) High resolution CT would ultimately lead to more accurate lung volume measurement but a smaller section thickness of as little as $1 \mathrm{~mm}$ would require much more than 30 seconds for completely scanning entire lungs. With scan thickness limited to $1 \mathrm{~cm}$ due to breath-holding limitations, the most important issue, then, is partial volume averaging between lung parenchyma and extraparenchymal tissue. It is therefore expected that some parenchymal lung tissue would be lost if maximal threshold value was inadvertently set too low in order to exclude extraparenchymal tissue and conversely, some extraparenchymal tissues would be included if the threshold was set too high in order to include lung tissue. Smaller collimation, higher pitch factor, and an overlapped reconstruction interval combined with smaller FOV and bone algorithm may lead a to better result. Further improvement may also occur if the patients are positioned identically during both CT scanning and spirometry.

In summary, total lung volume measured by spiral CT approximated the values measured by spirometry especially at higher upper limits of lung attenuation, thus pointing to the potential role of CT as a valuable means of evaluating lung function, aside from its already proven value in morphological depiction. An upper limit of $-250 \mathrm{HU}$ appeared to be the ideal level for optimal inclusion of intraparenchymal and exclusion of extraparenchymal tissue. Faster scanning, higher resolution, and the application of a variable threshold range upon individual bases may lead to more accurate results.

\section{REFERENCES}

1. Wu MT, Chang JM, Ghiang AA, Lu JY, Hsu HK, Hsu WH, Yang CF. Use of quantitative $\mathrm{CT}$ to predict postoperative lung function in patients with lung cancer. Radiology $1994 ; 191$ : 257-262

2. Archer DC, Coblentz CL, deKemp RA, Nahmias C, Norman G. Automated in vivo quantification of emphysema. Radiology 1993 ; $188: 835-838$ 
3. Heremans A, Verschakelen JA, Van Fraeyenhoven L, et al. Measurement of lung density by means of quantitative $C T$ scanning: A study of correlation with pulmonary function tests. Radiology $1993 ; 187: 291$

4. Newman KB, Lynch DA, Newman LS, et al. Quantitative computed tomography detects air trapping due to asthma. Radiology $1994 ; 193: 883$

5. Lamers RJ, Thelissen GR, Kessels AG, Wouters EF, van Engelshoven JM. Chronic obstructive pulmonary disease: Evaluation with spirometrically controlled CT lung densitometry. Radiology 1994; $193: 109-113$

6. Wandtke JC, Hyde RW, Fahey PJ, et al. Measurement of lung gas volume and regional density by computed tomography in dogs. Invest Radio/1986;21:108-117
7. Kalender WA, Rienmüller R, Seissler W, Behr J, Welke M, DiplInf HF. Measurement of pulmonary parenchymal attenuation: Use of spirometric gating with quantitative CT. Radiology $1990 ; 175$ : 265-268

8. Webb WR, Müller NL, Naidich DP. High-resolution CT technique. In : Webb WR, Müller NL, Naidich DP, eds. High-resolution CT of the lung. New York: Raven Press, $1992: 4-13$

9. Schlesinger AE, White DW, Mallory GB, Hildeboldt CF, Huddleston $\mathrm{CB}$. Estimation of total lung capacity from chest radiography and chest CT in children. AJR 1995;165:151-154

10. Kinsella M, Müller NL, Abboud RT, Morrison NJ, DyBuncio A. Quantification of emphysema by computed tomography using a "density mask" program and correlation with pulmonary function tests. Chest $1990 ; 97: 315-321$

\section{전폐 용적의 측정 :나선형 CT와 폐활량 검사와의 비교1}

${ }^{1}$ 아주대학교 의과대학 진단방사선과학교실

${ }^{2}$ 아주대학교 의과대학 호흡기내과학교실

3 연세대학교 의과대학 진단방사선과학교실

${ }^{4}$ 연세대학교 의과대학 해부학교실

${ }^{5}$ 울산대학교 의과대학 진단방사선과학교실

\section{정경일 · 박경주 · 이이형 ${ }^{2} \cdot$ 최규옥 $^{3} \cdot$ 임태환 $^{4} \cdot$ 정인혁 $^{5} \cdot$ 윤흔영 · 서정호}

목 적:폐의 기능적 검사방법으로서의 나선형 전산화 단층촬영술의 유용성을 평가하고자 하였다.

대상 및 방법: 19 명의 건강한 성인 폐를 단일 심흡기 상태에서 나선형 전산화 단층촬영하였다. 삼차원적 폐영상을 재구성 (최저 한계치 : $-1,000 \mathrm{HU}$, 최고 한계치 : $-150,-250,-350,-450 \mathrm{HU}$ )하여 전폐용량을 측정하였으며 그 결과를 폐활량검 사상의 전폐용량과 비교하였다.

결 과:폐활량검사상의 평균 전폐용량과 최고 한계치 $-150,-250,-350,-450 \mathrm{HU}$ 시 전산화 단층촬영상의 평균 전폐용 량은 각 $5.62,5.53,5.33,5.15,4.98$ L였고 두 검사방법 간의 절대 차이의 평균은 $0.17(3 \%), 0.32(5.6 \%), 0.48(8.5 \%), 0.65(11$. $5 \%$ ) L였다. 두 검사간의 회귀분석에 의한 회귀계수는 각 $0.99,0.97,0.95,0.94$ 였고 각 CT 감쇄 한계치에서 측정한 폐용량에 있어서 통계적으로 유의한 정확도의 차이는 없었다.

결 론:나선형 전산화 단층촬영으로 측정한 전폐용량은 폐활량검사상의 결과와 근접하였다. 나선형 전산화 단층촬영술 은 폐기능의 평가에 유용한 방법으로 사용될 가능성이 있다. 


\section{6년도 추계 진단방사선과 전공의 연수교육 안내}

제 목 : 1996년 10월 20일

장 소: 인촌강당(고려대학교내)

주 제 : 복부 질환의 영상진단

등 록 비 : 10,000 원

\begin{tabular}{cll}
\hline \hline 시 간 & \multicolumn{1}{c}{ 연 제 } & \multicolumn{1}{c}{ 연 사 } \\
\hline $09: 00-09: 40$ & 국소간질환의 감별진단 & 최병인 (서 울 의 대) \\
$09: 40-10: 10$ & 폐쇄성 황달 환자의 영상진단 & 이문규 (울 산 의 대) \\
$10: 10-10: 40$ & 담낭 질환의 영상진단 & 이동호 (경 희 의 대) \\
$10: 40-11: 00$ & 휴 식 & \\
$11: 00-11: 30$ & 췌장염의 영상진단 & 변재영 (가톨릭의대) \\
$11: 30-12: 00$ & 췌장암의 영상진단 & 강형근 (전 남 의 대) \\
$12: 00-12: 30$ & 기타 췌장 종양의 영상진단 & 이원재 (삼성의료원) \\
$12: 30-13: 30$ & 점 심 & \\
$13: 30-14: 00$ & 복막 / 후복막강 질환의 영상진단 & 박철민 (고 려 의 대) \\
$14: 00-14: 30$ & 부신 질환의 영상진단 & 백승연 (이 화 의 대) \\
$14: 30-15: 00$ & 비장 질환의 영상진단 & 조온구 (한 양 의 대) \\
$15: 00-15: 20$ & 휴 식 & \\
$15: 20-15: 50$ & 위장 질환의 영상진단 & 조준식 (충 남 의 대) \\
$15: 50-16: 20$ & 대장 질환의 영상진단 & 김기황 (연 세 의 대) \\
$16: 20-16: 50$ & 단순 복부 X-선 진단 & 한준구 (서 울 의 대) \\
\hline
\end{tabular}

